\title{
China wants 800,000 scientists by 1985
}

China would like to send 200 students a year to the UK, as part of a programme to produce 800,000 scientists by 1985 , a Royal Society delegation was told in China last week. The delegation met Vice-Premier Fang-Yi, who has responsibility for China's science policy, and other leading figures. To help meet its 800,000 target China hopes to send some 10,000 of its scientists and students to other countries. To do that China "will have to send them to several scientifically advanced countries", the leader of the delegation, Royal Society Foreign Secretary Dr M. G. P. Stoker, said on his return.

China will probably send most to the US, where the Presidential Science Adviser, Dr Frank Press, has expressed his willingness to accept them. Others will come to the UK, and to France, and some to Germany. China may favour the US and the UK, because the country appears to have chosen English as its second language. But France has signed a major scientific agreement with China emphasising technology, and in Germany the Max Planck Institutes are willing to take students.

China's programme is "very ambitious", said Dr Stoker. But under the gang of four the country had been scientifically "ten years in the wilderness". The scientists the Royal Society delegation met were mostly over 35 .

The Academia Sinica, which hosted the delegation, strongly emphasised China's needs in basic science. The Academy is responsible for 80 research institutes and three universities, and is "not the body primarily concerned" with the 'eight topics' developed at China's recent national conference on science and technology. "Our exchange programme is directed at all the basic sciences", said Dr Stoker.

Hao Pin. Head of the Foreign Relations Department of the Academy, has agreed to a major expansion of

\section{Conference time signals protests}

As the summer conference season gets under way, many western scientists, shocked at the sentencing of dissidents Orlov and Shcharanskii, have sought their own forms of protest against the action of the Soviet authorities.

At the International Luminescence Conference in Paris last month (the first international physics meeting since the Orlov trial), a "round table" and exhibition in defence of the Russian dissident was held. The protest was deliberately low key, and accordingly, collaboration with the Royal Society, to be ratified by a formal agreement after approval by the Society and the Academy. Apart from the 200 students, China wishes to send small delegations of senior research workers to visit one or two centres in the UK. Exchanging costs, the Royal Society hopes to send up to 20 senior scientists to lecture in China; but the Academy may increase the number of exchanges at its own cost.

The up to 200 students per year -100 at post-graduate and 100 at postdoctoral level-that the Academy wishes to send to the UK will be paid for by the Academy, with the Royal Society responsible for placing them. The students will stay for the usual periods: three years for post-graduates and two for post-doctorals, but none are expected to take degrees. Dr Stoker is concerned about language difficulties and the academic standards of the visitors-"I stressed that their standards must be very high",

\section{China studies education in foreign countries}

FORTY academics and state officials last month attended China's first Seminar to Study Education in Foreign Countries. In this they followed Mao's call to the Chinese people, reiterated in many of his policy speeches by Chairman Hua Kuo-Feng, that they should be good at absorbing whatever is valuable in things foreign, and turn it to their own use by combining it with their own inventiveness. Speaking at the Seminar, Vice-Minister of Education $\mathrm{Kao} \mathrm{Yi}$, said: "the starting point of our discussion is, basing ourselves on the realities of our revolution in education, to learn and put to use the strong points of other countries". Changing realities mean, one thinks, changing criteria on what are the strong points.

Among the papers read at the

the Soviet delegation did not feel itself obliged to withdraw from the conference as they might have done had the protest been more vociferous.

This month's meeting of the Fourteenth International Congress of Genetics in Moscow poses an even greater challenge to participants. Although none of the defendents in the recent trials was a biologist, in the Soviet Union there has always been a strong emotional link between physics and geneticists, dating back to the support given by the physicists to the "underground" geneticists during the days of Lysenkoism.

Moreover, a letter has just reached Amnesty International from Ivan
There will also be no small problem in placing these numbers particularly if they all want to go to the most prestigious laboratories. "We will have to spread them around a bit". The Royal Society may also have to take on extra staff to cope with the administration; or it may approach the British Council to help share the load. The formal agreement, Dr Stoker hopes, will be ready for the visit of a high level Chinese delegation in October led by a Vice President of the Academia Sinica, $\mathrm{Hu}$ K'e-Shih-or for next year, when the President of the Royal Society, Lord Todd, will be visiting China.

A separate intergovernmental agreement is also anticipated following Secretary of State Shirley Williams' visit to China recently, during which the UK and China reached an understanding in principle to exchange scientists and students. These exchanges would be extra to those planned by the Royal Society.

Robert Walgate

Seminar was one on "the Evolution of Primary and Secondary Schools in Post-War England". And there were discussions on the division of secondary school education into arts and science streams. A decision was made to bring forward the publication of two reports: "Outline of Education in Foreign Countries" and "Introduction to the World's Famous Universities".

T. B. Tang COMING SOON: Joseph Needham, the Cambridge historian of Chinese science and technology, visited China recently with Nature support to learn first hand of China's new enthusiasm for science. His three articles on the country's science policy, 1978, will appear in Nature shortly.

Kovalev, biologist and human-rights activist, now halfway through a sevenyear sentence. The letter, which inincludes a detailed description of camp conditions, calls upon western participants in the conference to express their support for Kovalev "by whatever means they consider appropriate".

Other current protests aim at preventing imprisonments-notably a petition from US and British scientists, including 11 Fellows of the Royal Society and two British Nobel Prizewinners, in defence of Grigorii Rosenshtein, a Moscow cyberneticist refusnik, who is threatened with a trial for "parasitism" (being without visible means of support).

Vera Rich 